TRUE STORIES đ゚ OTHER ESSAYS 

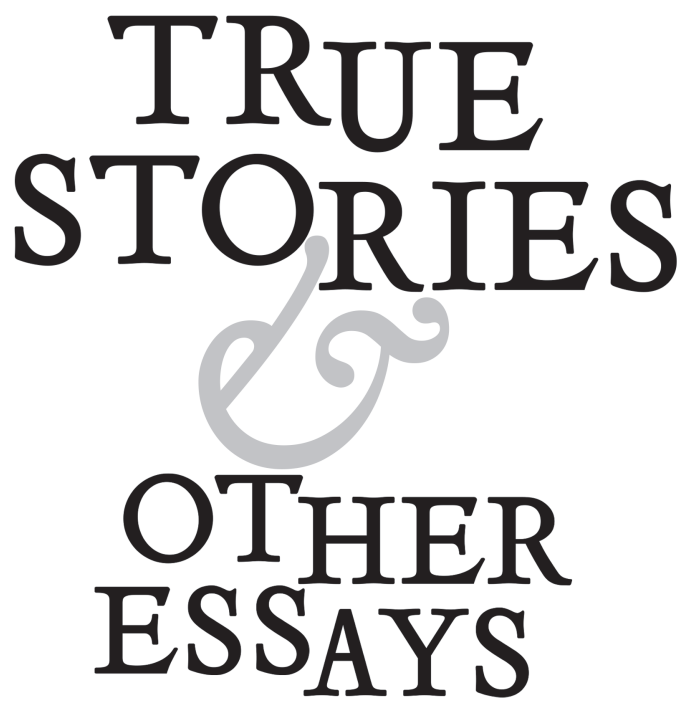

\section{FRANCIS SPUFFORD}

YALE UNIVERSITY PRESS

NEW HAVEN AND LONDON 
Copyright (c) 2017 Francis Spufford

All rights reserved. This book may not be reproduced in whole or in part, in any form (beyond that copying permitted by Sections 107 and 108 of the U.S. Copyright Law and except by reviewers for the public press) without written permission from the publishers.

For information about this and other Yale University Press publications, please contact: US Office: sales.press@yale.edu yalebooks.com

Europe Office: sales@yaleup.co.uk yalebooks.co.uk

Set in Minion Pro by IDSUK (DataConnection) Ltd

Printed in Great Britain by Gomer Press Ltd, Llandysul, Ceredigion, Wales

Library of Congress Cataloging-in-Publication Data

Names: Spufford, Francis, 1964- author.

Title: True stories : and other essays / Francis Spufford.

Description: New Haven, CT : Yale University Press, 2017. | Includes bibliographical references and index.

Identifiers: LCCN 2017021076 | ISBN 9780300230055 (hardback)

Subjects: | BISAC: LITERARY COLLECTIONS / Essays.

Classification: LCC PR6119.P84 A6 2017 | DDC 814/.6-dc23

LC record available at https://lccn.loc.gov/2017021076

A catalogue record for this book is available from the British Library.

10987654321 